\title{
Effects of Smoking on Metabolism and Excretion of Vitamin $B_{12}$
}

\author{
J. C. LINNELL,* в.SC. ; A. D. M. SMITH, $\dagger$ M.B., B.CH., B.SC., M.R.C.P. ; C. L. SMITH, $\dagger$ M.B., в.SC., M.R.C.P. \\ J. WILSON, $\ddagger$ M.B., B.S., B.SC., PH.D., M.R.C.P. ; D. M. MATTHEWS,* M.D., PH.D., M.C.PATH.
}

Experimental and clinical evidence both suggest that there is some connexion between the metabolism of vitamin $B_{12}$ and that of cyanide, and that smoking, which is associated with a high cyanide intake-for example, Darby and Wilson (1967)may adversely affect $B_{12}$ metabolism (Boxer and Rickards, 1952 ; Wokes and Picard, 1955 ; Braekkan, Njaa, and Utne, 1957; Wokes, 1958 ; Smith, 1961 ; Smith, Duckett, and Waters, 1963 ; Smith, 1964 ; Smith and Duckett, 1965 ; Matthews, Wilson, and Zilkha, 1965 ; Wilson and Matthews, 1966 ; Lindstrand, Wilson, and Matthews, 1966 ; Smith and Foulkes, 1966). The hypothesis that interconnected disturbances of cyanide/ $\mathbf{B}_{12}$ metabolism may be concerned in the pathogenesis of tobacco amblyopia, the retrobulbar neuritis of pernicious anaemia, Leber's optic atrophy, and certain tropical neurological syndromes apparently associated with a high cyanide intake from cassava (Smith, 1961; Wilson, 1965 ; Montgomery, 1965 ; Wilson and Langman, 1966 ; Monekosso and Wilson, 1966 ; Freeman, 1967 ; Chisholm, Bronte-Stewart, and Foulds, 1967) makes it essential to obtain further information about the interrelationships between an increased exogenous cyanide load, cyanide/thiocyanate metabolism, and bodily handling of vitamin $\mathrm{B}_{12}$.

So far the observations apparently providing a direct link between smoking and $\mathrm{B}_{12}$ metabolism are few. They include: (1) the observation that there may be a slight or moderate increase in cyanocobalamin in the plasma of some heavy smokers (Lindstrand, Wilson, and Matthews, 1966) ; (2) the finding that a larger proportion of serum $B_{12}$ is extractable in the absence of added cyanide in smokers than in non-smokers, which may be related to (1); and (3) the finding of a negative correlation between plasma cyanide concentration and that of total serum $B_{12}$ (Matthews et al., 1965 ; Wilson and Matthews, 1966). This last relationship could be connected with a tendency for chronic administration of cyanide to deplete body $\mathrm{B}_{12}$ stores (Braekkan et al., 1957), and the present investigation was made to explore this possibility further.

\section{Methods}

Two groups of healthy subjects were studied-18 nonsmokers (16 men and 2 women, mean age 27) and 19 smokers (16 men and 3 women, mean age 29). Eighteen of the smokers smoked cigarettes (mean consumption 20 per day) and one smoked a pipe ( 1 oz. (28 g.) per day). Twenty-four-hour urine collections were made into containers containing $1 \mathrm{~g}$. of neomycin, and aliquots of urine deep-frozen until analysis. Urine thiocyanate was estimated spectrophotometrically (Wilson and Matthews, 1966). Blood was taken for serum $B_{12}$ estimation on the day of the urine collection. Serum and urine $B_{12}$ were estimated by radioisotopic assay (Matthews, Gunasegaram, and Linnell, 1967) after extraction with cyanidecontaining buffer. \footnotetext{
- Department of Chemical Pathology, Westminster Medical School,
London $S$.W.1.

† Westminster Hospital, London S.W.1.
}

of Neurology, London W.C.1.

\section{Results and Discussion}

The results showed definite interrelationships between smoking, urine thiocyanate excretion, which is an index of the exogenous cyanide load, and serum and urine $B_{12}$ (Tables I and II ; Fig. 1). The mean thiocyanate excretion in smokers was more than double that in non-smokers. The urine $B_{12}$ excretion was significantly increased in smokers $(P=0.02)$. In smokers and non-smokers, taken together, there was a positive correlation between urine thiocyanate excretion and urine $B_{12}$ excretion. There was a negative correlation between thiocyanate excretion and serum $B_{12}$ concentration. In smokers alone, this latter correlation was more pronounced, and the tendency for high thiocyanate excretion to be associated with relatively low serum $B_{12}$ concentrations was striking (Fig. 2). Extrapolation of the regression line in Fig. 2-suggests that if the urine

TABLE I.-Serum $B_{12}$, Urine $B_{1}$ Excretion, and Urine Thiocyanate

\begin{tabular}{|c|c|c|c|c|}
\hline \multicolumn{2}{|c|}{ Estimation } & Smokers & Non-8mokers & \\
\hline \multicolumn{2}{|c|}{ 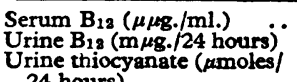 } & $\begin{array}{r}.444 \\
81.2 \pm 36.8(18) \\
8.7(16)\end{array}$ & $\begin{array}{l}472 \pm 26 \cdot 3(18) \\
60 \cdot 3 \pm 7 \cdot 9(16)\end{array}$ & $\begin{aligned} 0.6 & >P>0.5 \\
P & =0.02 \dagger\end{aligned}$ \\
\hline 24 hours) & $\cdots \quad \quad$. & $207 \cdot 8 \pm 15 \cdot 8(19)$ & $90.5 \pm 7.0(18)$ & $P \ll 0.001$ \\
\hline
\end{tabular}

- Mean \pm S.E.M. (n). t Using $\log _{2} 0$.

TABLE II.-Correlations Between Serum $B_{12}$, Urine $B_{1,}$ Excretion, and Thiocyanate Excretion in Smokers and Non-smokers

\begin{tabular}{|c|c|c|c|}
\hline & Group & $\mathbf{r}$ & \\
\hline 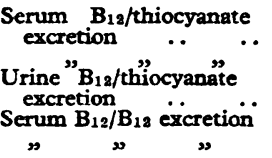 & $\begin{array}{l}\text { Smokers and non-smokers } \\
\text { Smokers only } \\
\text { Smokers and non-smokers } \\
\text { Smokers only }\end{array}$ & $\begin{array}{l}-0.42 \\
-0.57 \\
+0.53 \\
-0.19 \\
-0.24\end{array}$ & $\begin{aligned} 0.02 & >P>0.01 \\
0.02 & >P>0.01 \\
0.01 & >P>0.001 \\
P & >0.9 \\
P & >0.9\end{aligned}$ \\
\hline
\end{tabular}

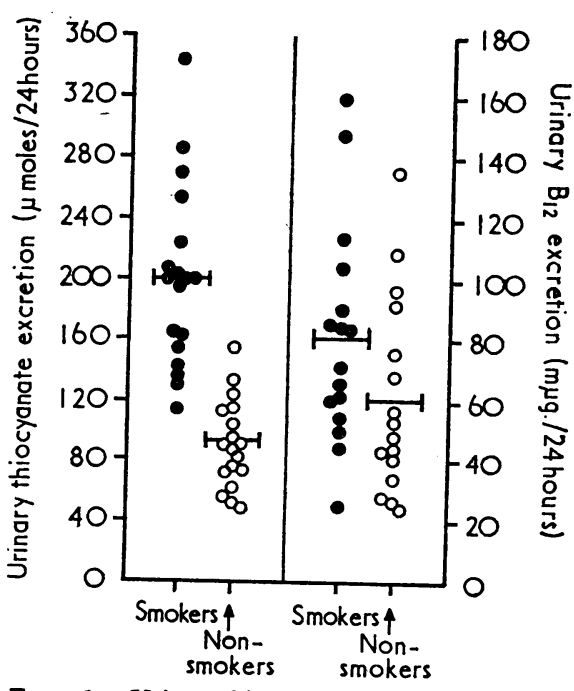

Fi6. 1.-Urine thiocyanate excretion and wrine $B_{12}$ excretion in smokers and non-
smokers. 
thiocyanate excretion reached $300-400 \mu$ moles/24 hours, subnormal serum $B_{12}$ concentrations would be expected.

Sumnarized, the results show that urine excretion of $B_{12}$ is raised in smokers, and that a high excretion of thiocyanate tends to be associated with an increase in $\mathrm{B}_{12}$ excretion and a relatively low serum $B_{12}$ concentration. The association between high thiocyanate excretion and low serum $B_{12}$ concentration, which is especially marked in smokers, recalls that between

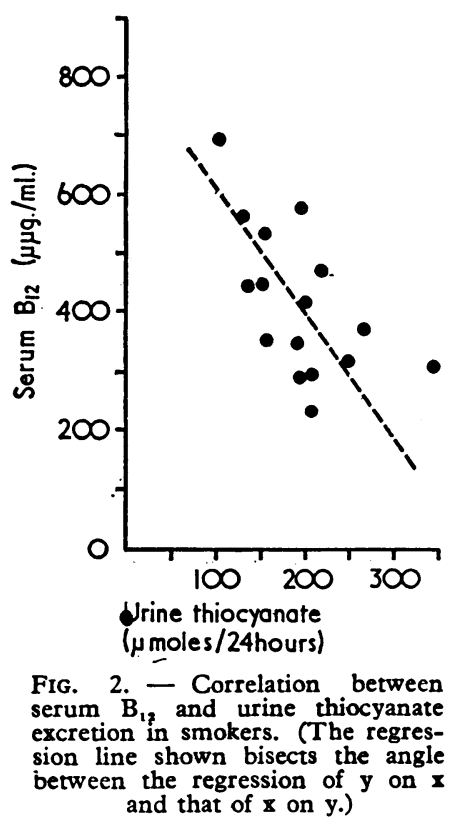

high serum cyanide concentration and low serum $B_{12}$ (Wilson and Matthews, 1966); these two observations are probably related. More than one hypothesis might be put forward to explain these results. Thus it could be postulated that subjects with relatively low serum $B_{12}$ concentrations have a reduced ability to detoxicate cyanide by pathways involving this vitamin, so that detoxication by the thiocyanate pathway is increased. This would not, however, readily explain the association between high thiocyanate excretion and high excretion of $B_{12}$.

Alternatively, the low serum $B_{12}$ concentration might reflect $B_{12}$ depletion, possibly resulting from conversion of tissue cobalamins to cyanocobalamin, a form relatively readily excreted by the kidney (Nyberg, Saarni, and Gräsbeck, 1961 ; Samson, Yeh, and Chow, 1961 ; Glass, Skeggs, Lee, Jones, and Hardy, 1962 ; Okuda and Tantengco, 1962). Though chromatography of serum $B_{12}$ in smokers (Lindstrand et al., 1966) showed only small or moderate amounts of cyanocobalamin in some of the group, it did not exclude the possibility that a minor degree of conversion occurred in all. However, the increment in $\mathrm{B}_{12}$ excretion associated with smoking (mean $0.021 \mu \mathrm{g}$./day, maximum probably about $0.1 \mu \mathrm{g}$./day-Fig. 1) is so small in relation to the amount probably absorbed daily (2-5 $\mu \mathrm{g}$.) and to the liver stores (about $2,000 \mu \mathrm{g}$.) that it would seem unlikely that appreciable depletion could be caused in healthy people by this means. This consideration, together with the very poor correlation between serum $B_{12}$ and urine $B_{12}$ excretion, suggests that some factor other than increased renal excretion of $B_{12}$ must operate to produce the relation between high thiocyanate excretion and low serum $B_{12}$ concentration. It is possible that high plasma cyanide concentrations disturb the equilibrium between serum and urine $B_{12}$.

At the moment the main significance of this work is that it shows further definite, if unexplained, interrelationships between smoking, cyanide metabolism, and bodily handling of vitamin $B_{12}$, and gives further support to the idea that high loads of cyanide might produce derangements of $\mathrm{B}_{12}$ metabolism. The effects of smoking are slight in healthy subjects, but in patients already in marginal $B_{12}$ balance they might become significant.

\section{Summary}

In view of evidence suggesting that there is a connexion between the metabolism of vitamin $B_{12}$ and that of cyanide, and that smoking, which is associated with a high cyanide intake, may disturb the metabolism of $B_{12}$; serum $B_{21}$, urine $B_{12}$ excretion, and urine thiocyanate excretion (an index of cyanide detoxication) have been measured in healthy smokers and non-smokers.

The results show that urine $B_{12}$ excretion is raised in smokers and that a high thiocyanate excretion is associated with an increase in $B_{12}$ excretion and a relatively low serum $B_{12}$ concentration. The increase in $B_{12}$ excretion seems insufficient to account for the reduction in serum $B_{12}$ concentration, which may be the result of disturbance of the equilibrium between serum and tissue $B_{12}$ by high plasma cyanide concentrations. The work supports the idea that a high cyanide intake might produce derangements of $\mathrm{B}_{12}$ metabolism.

The work was supported by a grant from the Wellcome Trust.

\section{REFERENCES}

Boxer, G. E., and Rickards, J. C. (1952). Arch. Biochem., 39, 7. Braekkan, O. R., Njaa, L. R., and Utne, F. (1957). Acta pharmacol. (Kbh.), 13, 228 .

Chisholm, I. A., Bronte-Stewart, J., and Foulds, W. S. (1967). Lancet, 2,450 .

Darby, P. W., and Wilson, J. (1967). Brit. F. Ophthal., 51, 336.

Freeman, A. G. (1967). Lancet, 2, 422.

Glass, G. B. J., Skeggs, H. R., Lee, D. H., Jones, E. L., and Hardy, W. W. (1962). In Vitamin $B_{13}$ und Intrinsic Factor, edited by H. C Heinrich, p. 673. Stuttgart.

Lindstrand, K., Wilson, J., and Matthews, D. M. (1966). Brit. med. J., 2, 988 .

Matthews, D. M., Gunasegaram, R., and Linnell, J. C. (1967). 7. clin. Path., 20, 683.

Matthews, D. M., Wilson, J., and Zilkha, K. J. (1965). F. Neurol. Neurosurg. Psychiat., 28, 426.

Monekosso, G. L., and Wilson, J. (1966). Lancet, 1, 1062.

Montgomery, R. D. (1965). Amer. F. clin. Nutr., 17, 103.

Nyberg, W., Saarni, M., and Gräsbeck, R. (1961). Nature (Lond.), 189, 764.

Okuda, K., and Tantengco, V. (1962). Proc. Soc. exp. Biol. (N.Y.), 110, 396.

Samson, G. D., Yeh, S. D. J., and Chow, B. F. (1961). Fed. Proc., 20 451.

Smith, A. D. M. (1961). Lancet, 1, 1001.

Smith, A. D. M. (1964). Lancet, 2, 668.

Smith, A. D. M., and Duckett, S. (1965). Brit. F. exp. Path., 46, 615.

Smith, A. D. M., Duckett, S., and Waters, A. H. (1963). Nature (Lond.), 200, 179.

Smith, A. D. M., and Foulkes, M. (1966). Nature (Lond.), 209, 919.

Wilson, J. (1965). Clin. Sci., 29, 505.

Wilson, J., and Langman, M. J. S. (1966). Nature (Lond.), 212, 787.

Wilson, J., and Matthews, D. M. (1966). Clin. Sci., 31, 1.

Wokes, F. (1958). Lancet, 2, 526.

Wokes, F., and Picard, C. W. (1955). Amer. J. clin. Nutr., 3, 383. 